DOI 10.14746/ssp.2014.4.3

Magdalena SZKUDLAREK

Uniwersytet im. Adama Mickiewicza w Poznaniu

\title{
Kapelusz kontra fez - o roli nakryć głowy w europeizacji Turcji
}

Punktem wyjścia dla rozważań dotyczących znaczenia nakryć głowy
w powstaniu i modernizacji państwa tureckiego, której to kwestii poświęcony jest niniejszy artykuł, uczyniono założenia szkoły myślenia określanej jako ANT (ang. actor network theory) w interpretacji francuskiego socjologa i filozofa nauki Bruno Latoura. Ze względu na wymuszoną formą publikacji skrótowość analizy, autorka zdecydowała ograniczyć się jedynie do tych aspektów koncepcji ANT, które wydają się być najbardziej istotnymi dla omawianej kwestii. I tak, jak pisze Latour, każda nauka aspirująca do badania tego, co społeczne, rozpoczać się musi od postawienia pytania o to, kim bądź czym są uczestnicy działania. Odpowiedź na nie może zaś doprowadzić do stwierdzenia udziału w nich nie tylko osób, ale również czynnika pozaludzkiego (Latour, 2010, s. 539). Innymi słowy, autor ten odrzuca tradycyjne rozumienie świata społecznego, z którego w nieuzasadniony według niego sposób wykluczono cały szereg aktorów, określanych ogólnie jako rzeczy. Przekonanie to uzasadnia twierdzeniem o bezzasadności tworzenia sztucznej dychotomii tego, co materialne i tego, co przynależne do świata społecznego, twierdząc, że to właśnie przedmioty stanowią oparcie dla kruchych relacji czy procesów społecznych. Zaznacza jednocześnie, iż celem takiego podejścia nie jest tworzenie idealnej symetrii pomiędzy tym, co ludzkie, a tym, co materialne, odrzuca jednak tworzenie a priori asymetrii stawiającej te czynniki w opozycji wobec siebie. Idąc dalej, Latour podkreśla, iż rzeczy nie determinują procesów, nie inicjują ich, ale inspirują, ułatwiają, zachęcają bądź zniechęcają do działania, mogą stać się ich symbolami czy kołem napędowym, pełnią więc rolę 'zapośredniaczy', niedocenianych, acz nieodłącznych ogniw procesów społecznych. Aby więc te ostatnie mogły być poddane rzetelnej analizie, koniecznym jest zbadanie tego, kim są ich aktorzy, w tym aktorzy pozaludzcy. Tak bowiem, jak nie sposób mówić o bitwie, opisując osobno żołnierzy i skład broni, tak niemożliwym jest badanie zjawisk społecznych z pominięciem któregokolwiek z ich uczestników. Uczestnikiem jest zaś „każda 
rzecz, która zmienia stan rzeczy, która wprowadza jakąś różnicę" (Latour, 2010, s. 537), bez której obserwowany proces wyglądałby choćby nieco inaczej. Nie chodzi więc tu, jak już wspomniano, o czynienie z rzeczy ostatecznych czy głównych sprawców, ale o dostrzeżenie ich sprawczości jako takiej, rozumianej jako udział w działaniu.

\section{Skąd się wziąl fez?}

Celem niniejszego artykułu jest podjęcie próby zastosowania nakreślonego podejścia na gruncie analizy zjawisk z zakresu stosunków międzynarodowych, a dokładniej procesu budowy i jednoczesnej europeizacji Republiki Turcji, której powstanie proklamowano 29 października 1923 roku. Jednym z najważniejszych symboli kemalistowskiej rewolucji, która zapobiegła ostatecznej dezintegracji terytorialnej chylącego się ku upadkowi Imperium Osmańskiego, stał się kapelusz. Aby jednak mówić o roli, jaką to i inne nakrycia głowy odegrały w historii współczesnej Turcji, konieczne jest wcześniejsze odniesienie do historycznego kontekstu narodzin tego państwa.

Mimo że rodzaj nakrycia głowy noszony przez mężczyzn świadczył o ich statusie społecznym właściwie od zarania istnienia społeczności turkijskich ${ }^{1}$, dopiero w XIX wieku stało się ono narzędziem świadomej polityki prowadzonej najpierw przez władców osmańskich, a następnie przez włodarzy republiki. Co więcej, rola, w jakiej każde z nich było wykorzystywane i cele, jakim służyło, ewoluowały wraz z kolejnymi zmianami polityki państwa. To zaś wpisuje się w istotne dla przyjętego tu podejścia teoretycznego stwierdzenie Bruno Latoura, że „narzędzia [...] są aktorami, czy dokładniej uczestnikami przebiegu działania, czekającymi na nadanie im figuracji” (Latour, 2010, s. 538). Figuracja owa, rozumiana jako nadanie nowej formy, nowego kształtu, powoduje, iż rzecz zaczyna niejako ‘żyć własnym życiem', a więc przechodzić przez kolejne etapy, wcielenia, nadawane jej w trakcie trwania działania. Takie dokładnie zjawisko zaobserwowane może być właśnie na przykładzie znaczeń politycznych, jakie na przestrzeni lat nadawano w Turcji różnym rodzajom nakrycia głowy, takim jak fez, kapelusz czy chusta (ar. hijāb, tur. başörtüsü).

1 Świadczy o tym choćby fakt nadawania kamieniom nagrobnym takiego kształtu, jaki charakteryzował nakrycie głowy noszone za życia przez zmarłego. Dzięki temu nawet po jego śmierci stwierdzone być mogło, czy umarł jako pasza, urzędnik państwowy czy może obywatel którejś z niższych kategorii. 
Mimo tego, że współcześnie fez i jego następca kapelusz kojarzą się przede wszystkim z okresem Atatürka i zachodzącymi wówczas przemianami polityczno-obyczajowymi, pierwszemu z nich zaczęto przypisywać znaczenie symbolu politycznego już całe stulecie wcześniej. Rządy sułtana Mahmuta II (1808-1839) to pierwszy w historii Imperium Osmańskiego okres rzeczywistego zainteresowania Europa ${ }^{2}$, tym razem nie w kontekście zysków z wymiany handlowej czy podboju ziem, ale celem obserwacji zachodniego stylu życia i wyłuskania zeń tego, co potencjalnie możliwe do zaszczepienia na gruncie osmańskim. Innymi słowy, Mahmut II, sułtan reformator, który zlikwidował coraz bardziej niezależny od dworu korpus janczarów (tur. yeniçeri), jako jeden z pierwszych władców Imperium dostrzegł potrzebę jego modernizacji. Pewnym przejawem, wówczas jeszcze bardzo nieśmiałego czerpania z zachodnich wzorców, był dekret w sprawie ubioru (tur. Klyafet Nizamnamesi) z 1828 roku, w którym zakazano noszenia tradycyjnych turbanów i innych ubiorów typowych dla osmańskiej obyczajowości. Turban zastąpiony miał być przez fez (pojawiły się również spodnie i marynarka, dotąd w imperium nieznane) - nakrycie głowy w kształcie ściętego stożka, wykonane z filcu najczęściej w kolorze bordowym, ozdobione czarnym frędzlem. Początkowo do jego noszenia zobowiązani zostali określonej rangi urzędnicy i oficerowie, a w ciągu kilkudziesięciu lat stał się on nieodłącznym elementem męskiego ubioru w całym Imperium. Skąd jednak wziął się fez i jakich trendów był zwiastunem? Otóż, pierwotnym pomysłem sułtana było rozpowszechnienie na dworze osmańskim popularnych z państwach zachodniej Europy kapeluszy, kojarzących się z brytyjskimi dżentelmenami, do których upodobnić pragnęły się elity imperium. Problemem okazał się jednak kształt kapelusza, a dokładniej jego rondo, uniemożliwiające odbywanie muzułmańskiej modlitwy (ar. namâz, tur. namaz) ${ }^{3}$. Ponadto, o ile dla bliskich sułtanowi kręgów kapelusz mógł jawić się jako symbol owej upragnionej europejskości, o tyle mieszkańcom anatolijskiej prowincji kojarzył

2 W artykule wielokrotnie padają określenia ‘państwa Europy zachodniej’, ‘europejski', 'modernizacja', 'na wzór zachodni' itp. Wszystkie one dotyczą tego samego obszaru geograficznego, tożsamego z obszarem dzisiejszej Unii Europejskiej. W kontekście mody czy ubioru w największej mierze dotyczą one ówczesnej Francji, Wielkiej Brytanii i Niemiec. Określenie 'europeizacja' oznacza adaptację realizowanych na wskazanym powyżej obszarze wzorców politycznych, prawnych i kulturowych.

3 Modlitwa taka wymaga wykonywania w pozycji klęczącej pokłonów do przodu i uderzania czołem o podłogę, co rondo kapelusza wydatnie by utrudniało. 
się on z niewiernymi, próbującymi dokonać rozbioru ich ojczyzny (Kołodziejczyk, 2000, s. 121). Rozwiązaniem kompromisowym okazało się nakrycie głowy sprowadzone z obszarów dzisiejszego Maroka, którego nazwa dawnej stolicy - Fez - dała początek określaniu go właśnie mianem fezu. W ten sposób uważany za symbol konserwatywnych ulemów ${ }^{4}$ turban zastąpiony został 'postępowym' fezem, mającym stanowić namiastkę europejskiego kapelusza. Innymi słowy, sprowadzony z Maroka, ale wywodzący się z czasów starożytnych fez stał się symbolem pierwszego w historii Imperium wyraźnego zwrotu ku europejskości, stanowiącej w oczach ówczesnych władz remedium na nasilające się problemy wewnętrzne. Wyrazem wagi, jaką przywiązywano do upowszechnienia się tego nakrycia głowy, było wydzielenie w sułtańskiej administracji specjalnego urzędu do spraw fezu oraz budowa w 1839 roku Feshane ${ }^{5}$ - fabryki zaopatrującej w fezy mieszkańców całego imperium. Co więcej, kolor i sposób ozdobienia fezu ściśle odzwierciedlał pozycję jego użytkownika, nie było możliwości noszenia nakrycia przypisanego 'nie do swojej funkcji'. W efekcie, jedynie wśród najwyższych rangą wojskowych funkcjonowały 43 jego rodzaje, zaś wśród urzędników dworskich naliczyć ich można było 27 (Sitembölükbaş1, 1996, s. 62-69).

Jak wspomniano, w ciągu kilkudziesięciu lat, które minęły od sprowadzenia fezu do Stambułu, stał się on nakryciem głowy powszechnym w całym imperium, co wpisywało się w modernizacyjne trendy, jakie zapanowały w okresie Tanzimâtu (osm. tanzimat-i hayriye - dobroczynne reformy). Pojęciem tym określa się w tureckiej historiografii projekt szeroko zakrojonej reorganizacji państwa osmańskiego, mający na celu uczynienie go nowocześniejszym i zbliżonym do tego, czym było wówczas państwo w rozumieniu europejskim. Tak, jak na gruncie prawnym przejawem modernizacji było czerpanie wzorców z kodeksów państw zachodnich, tak najbardziej 'zewnętrznym' i widocznym gołym okiem objawem europeizacji osmańskiego społeczeństwa było w tym okresie morze fezów górujących nad ulicami Stambułu. Nakrycie głowy, do którego noszenia zostali zobowiązani z czasem wszyscy mężczyźni wyznania muzułmańskiego ${ }^{6}$ zostało więc wykorzystane jako narzędzie zainicjowania głębo-

${ }^{4}$ Muzułmański uczony.

5 Dziś pełni rolę centrum targowego w Stambule.

${ }^{6}$ Przedstawiciele mniejszości religijnych (Żydzi, Ormianie, Grecy) również nosili fezy, jednak w kolorach i kształtach odmiennych od tych używanych przez muzułmanów. 
kiej, wielopłaszczyznowej modernizacji imperium. Stanowić miała ona remedium na problemy i patologie dławiące je od wewnątrz, w tym posuniętą do niebotycznych rozmiarów korupcję, przerost i nieskuteczność administracji, głębokie podziały społeczne, niewydolny system prawny i podatkowy oraz nieustającą rywalizację (zwieńczoną nierzadko skrytobójstwami) o najwyższe urzędy. Ponieważ ocena przeprowadzonych w owym okresie reform nie stanowi przedmiotu analizy, autorka ograniczy się wyłącznie do stwierdzenia, że z czasem okazały się one jedynie odsunięciem nieuchronnego już wtedy upadku imperium. Innymi słowy, o ile nie sposób zaprzeczyć postępowi, jakiego wówczas dokonano, o tyle zmiany te okazały się służyć wyłącznie przedłużaniu agonii państwa osmańskiego.

Tym, który zapobiegł ostatecznej dezintegracji terytorialnej i rozbiorowi i tak już okrojonych terytoriów imperium przez mocarstwa europejskie, okazał się generał Mustafa Kemal, autor zwycięskiej dla Osmanów bitwy o Çanakkale ${ }^{7}$ z przełomu 1915 i 1916 roku. Potyczka, która w założeniu miała doprowadzić państwa Ententy do zdobycia Stambułu, zakończyła się ich druzgocącą porażką, stanowiącą jednocześnie istotny zwrot w I wojnie światowej. Mustafa Kemal Paşa, porywając do walki całkowicie, wydawało się, zrezygnowanych i pogodzonych z losem żołnierzy, i zapobiegając podbiciu Stambułu, otworzył zupełnie nową kartę w historii tureckiej państwowości. Aby jednak można było mówić o jej przetrwaniu, konieczna stała się głęboka, radykalna przebudowa systemu, który doprowadził Osmanów na skraj upadku. Jej autorem miał się stać kilka lat później właśnie generał Mustafa Kemal. Zanim jednak do tego doszło, zgodnie z zasadą, wedle której wygrana bitwa nie oznacza wygranej wojny, koniecznym było wyparcie wojsk przeciwnika z jak największych obszarów tak, by zapobiec całkowitemu rozbiorowi ziem, które pozostały z terytoriów państwa sułtańskiego. Choć oczywistym było, iż zachowanie go choćby w okrojonym kształcie nie będzie możliwe, generał podjął wyzwanie uchronienia przez zaborem chociaż części ziem zagarniętych przez Grecję i Wielką Brytanię. Co więcej, czynił to właściwie niezależnie od rezydującego w Stambule rządu sułtańskiego, który na tym etapie nie ukrywał już nawet całkowitej uległości wobec potęg europejskich. Wraz

W zachodniej historiografii częściej używana jest grecka nazwa Gallipoli, którą spośród polskich historyków posługuje się m.in. Jan Reychman czy Tomasz Wituch. Mimo tego autorka zdecydowała się na zastosowanie formy tureckiej, podobnie, jak czyni to w przypadku innych używanych w artykule określeń. 
z kolejnymi zwycięskimi bitwami zmieniał się również charakter działalności Mustafy Kemala - z wybitnie wojskowej w wojskowo-polityczna, opozycyjną wobec władzy sułtana. Momentem symbolicznym stało się wypowiedzenie posłuszeństwa Mehmetowi VI przez część armii osmańskiej i decyzja o kontynuowaniu walk wyzwoleńczych właśnie u boku generała. W ten sposób z wybitnego dowódcy stał się on również liderem politycznym, wokół którego tworzyć zaczął się konkurencyjny, choć w świetle prawa nielegalny ośrodek władzy. Momentem przełomowym w walkach okazał się rok 1921, w którym wojska Mustafy Kemala zyskały przewagę na tyle dużą, by zmusić europejskie mocarstwa do negocjacji w kwestiach terytorialnych. Warunki jednak, jakie postawiono stronie tureckiej okazały się nie do zaakceptowania, niewiele bowiem odbiegały od propozycji zawartych w traktacie z Sèvres ${ }^{8}$. To zaś skłoniło generała do ataku, który zaowocował w połowie 1922 roku ostatecznym przesunięciem się przewagi na stronę turecką i zmusił siły greckie do wycofania się z Izmiru (gr. Smyrna). Od tego momentu wiadomo było, że ośrodkiem decyzyjnym nie będzie już izolowany w okupowanym Stambule rząd sułtański, ale nowy, kemalistowski rząd w Ankarze. Ten zaś, jako że nie uznawał władz sułtańskich, zapowiedział odrzucenie i uznanie za niebyłe wszystkich przyjętych przez nie zobowiązań i umów, a pierwszą, której przyjęcia miał odmówić, był sankcjonujący rozbiór Turcji traktat z Sèvres. W ten sposób potwierdziło się przejęcie inicjatywy przez obradujący w Ankarze od 1919 roku Kongres Narodowy, który stał się zaczątkiem rządu, mającego w ciągu najbliższych lat podjąć wyzwanie budowy zupełnie nowego państwa tureckiego. Istotną zapowiedzią zmian, jakie miały się dokonać, było przyjęcie w 1921 roku przez Wielkie Zgromadzenie Narodowe ${ }^{9}$ tymczasowej ustawy konstytucyjnej (osm. Teşkilât-ı Esasiye Kanunu), w której rola sułtana-kalifa została całkowicie pominięta. To zaś zwiastowało rewolucyjne zmiany ustrojowe, jakie miały nastąpić w ciągu kolejnych lat - godność sułtańska formalnie zniesiona została 1 listopada 1922 roku, a półtora roku później, w marcu 1924 roku ten sam los spotkał godność kalifa. Wcześniej jednak, 29 października

8 Traktat pokojowy pomiędzy Turcją sułtańską a państwami Ententy, stanowiący de facto rozbiór Turcji i podział terytoriów pozostałych z Imperium Osmańskiego pomiędzy potęgi europejskie.

9 Istniejący w Stambule parlament został oficjalnie zamknięty w kwietniu 1920 roku na skutek zajęcia go przez zachodnie wojska okupacyjne. Wielkie Zgromadzenie Narodowe, zdominowane przez kemalistów, utworzone zostało 23 kwietnia 1920 roku. 
1923 roku proklamowano powstanie Republiki Turcji, której prezydentem został generał Mustafa Kemal nazwany później Atatürkiem - ojcem wszystkich Turków ${ }^{10}$. W ten sposób w ciągu niecałych czterech lat od upadku Imperium Osmańskiego na jego gruzach stworzone zostało zupełnie nowe państwo. Najważniejszą ambicją jego twórców z prezydentem Mustafą Kemalem na czele była jak najszybsza, ale również jak najgłębsza europeizacja Turcji, oparta na całkowitym oderwaniu się od osmańskiego dziedzictwa. Jednym z najwcześniejszych tego przejawów była decyzja o przeniesieniu stolicy do Ankary, ze Stambułu, który w oczach kemalistów uosabiał całość zła i wypaczeń, które doprowadziły do upadku imperium. Tym zaś, w czym szczególnie upatrywano powodów tego upadku były w pierwszej kolejności religijność i wielonarodowość państwa sultańskiego ${ }^{11}$.

\section{Czy kapelusz ma większą sprawczość niż fez?}

Istotą podjętej przez Atatürka radykalnej przebudowy państwa było programowe odrzucenie osmańskiej przeszłości, w której upatrywał on źródła zacofania i degeneracji, stanowiących bezpośrednią przyczynę upadku imperium. Celem podjętych reform było więc wyrugowanie ze sfery publicznej, a najlepiej także prywatnej, wszelkich pozostałości państwa osmańskiego, w tym przede wszystkim religii i wszystkiego, co się z nią łączy. Ofensywa laicyzmu, która rozpoczęła się od likwidacji bractw religijnych, a następnie objęła zastąpienie kalendarza hidżry kalendarzem gregoriańskim (1925), przyjęcie nowego kodeksu cywilnego wprowadzającego monogamię i śluby cywilne jako jedyną formę zawarcia związku małżeńskiego (1926), zastapienie alfabetu arabskiego łacińskim (1928), wprowadzenie obowiązku przyjęcia nazwiska na wzór europejski

10 Oficjalnie przydomek ten przyjął jako własne nazwisko w 1934 roku, na mocy ustawy nakazującej wszystkim obywatelom Turcji wybór nazwiska na wzór europejski. Dotąd stosowane były określenia typu Mehmet Paşa-pasza Mehmet, Osman Ticaretçi - kupiec Osman.

11 Jako że kwestia przekształcania wielonarodowego i wieloetnicznego społeczeństwa Imperium w czysto turecki naród, którego praojczyzną jest Anatolia, pozostaje dość luźno związana w przedmiotem tej analizy, nie zostaje w niej poruszona. Pamiętać jednak należy, że stworzona przez Atatürka koncepcja jednolitego etnicznie narodu tureckiego i wynikająca $\mathrm{z}$ niej polityka nierozpoznawania mniejszości stanowiły i do dziś stanowią fundament państwa tureckiego. 
(1934) oraz uczynienie niedzieli, zamiast piątku, dniem wolnym od pracy (1935). Dużo jednak wcześniej, niecałe dwa lata po powstaniu republiki, wprowadzono tak zwaną ustawę kapeluszową (tur. şapka kanunu; pełna nazwa: tur. Şapka iktisası hakkında kanun, pol. Ustawa o obowiazku noszenia kapeluszy), która, wraz z poprzedzającymi ją wydarzeniami, stanowiła zapowiedź nadchodzącej rewolucji.

W mniemaniu Mustafy Kemala jedyną szansą na zachowanie suwerennej egzystencji państwa tureckiego było porzucenie wszystkiego tego, co 'osmańskie' na rzecz tego, co 'tureckie', a więc nowoczesne i europejskie. Tym zaś, co w pierwszej kolejności, podczas każdego spaceru po ulicy, rzucało się w oczy Atatürka najbardziej i przywodziło na myśl wzgardzoną osmańską tradycję, był zdobiący każdą męską głowę fez. Fez, który stulecie wcześniej uczyniony został przez sułtana Mahmuta II narzędziem zwrotu ku państwom Europy zachodniej i modernizacji, jakiej imperium miało zostać poddane, tak mocno zespolił się z osmańską kultura, że dla prezydenta Mustafy Kemala stanowił wręcz uosobienie wstecznictwa i degeneracji państwa sułtańskiego. Innymi słowy, tak, jak dla Mahmuta II symbolem zacofania i zbliżającego się upadku był tradycyjny turban, tak twórca świeckiej republiki znaczenie takie przypisał fezowi. W rezultacie, nakrycie głowy, o którym właściwie do ostatnich dni istnienia imperium myślano jako o kwintesencji europejskości, w pierwszych latach republiki zdegradowane zostało do wstydliwej pozostałości po dynastii osmańskiej. W ciągu niecałego stulecia fez z narzędzia modernizacji społeczeństwa stał się symbolem jego upadku, a miejsce jego zająć miał kapelusz. Zanim jednak przedstawiona zostanie jego rola w kolejnej już próbie uczynienia Turcji bardziej europejska, warto wspomnieć o źródłach umiłowania Atatürka dla tego akurat nakrycia głowy. Jedna z najwcześniejszych obserwacji, jakie poczynił on w tej materii pochodzi z 1908 roku, kiedy jeszcze jako wojskowy podległy dowództwu sułtańskiej armii podróżował kabrioletem po Sycylii. Największe zainteresowanie i kpiny miejscowych dzieci wzbudził właśnie zdobiący jego głowę fez, nieprzypominający w niczym noszonych w ówczesnej Europie nakryć głowy. Bardziej jednak niż owe zniewagi zezłościła go refleksja, jaką poczynił wysłuchując ich: „Bardziej niż na złe wychowanie dzieci zezłościłem się na to, że my Turcy staliśmy się niewolnikami tego jakże niecywilizowanego nakrycia głowy" (Atay, 2004, s. 468). Podobne wydarzenia miały miejsce również w pierwszych, po proklamowaniu republiki, zagranicznych podróżach Atatürka i jego świty. Jedna z nich dotyczy podróży przez Belgrad do Paryża, którą prezydent odbywał w towarzystwie swego 
przyjaciela, dość jednak opornego na zmiany w zakresie ubioru. Mimo usilnych próśb ze strony Mustafy Kemala, towarzysz jego nie zgodził się na rezygnację z fezu, co wywołało nie tylko kpiny podczas postoju w Belgradzie, ale również wyrażoną słowami „A cóż to za strój okropny?!” krytykę ze strony attaché wojskowego witającego delegację na dworcu w Paryżu (Aydemir, 1981, s. 234-235). Podobnych anegdotek przytaczać można wiele, a każda kolejna będzie rzucać nieco więcej światła na pozornie niezrozumiałą nienawiść prezydenta do fezu. Jeśli wziąć bowiem pod uwage jego największą ambicję, którą było wprowadzenie Turcji - tak pod względem kulturowym, jak i politycznym, w poczet państw europejskich - symbolizujący osmańskość, fez rzeczywiście mógł jawić się jako najważniejszy symbol wszystkiego tego, czym republika miała pogardzać. Już podczas posiedzenia kemalistowskiego Kongresu Narodowego w lipcu 1919 roku przedstawił Mustafa Kemal pięć celów, jakie zrealizowane miały być tuż po upadku Imperium, którego nota bene nikt jeszcze wówczas pewien być nie mógł. Obok ustanowienia republikańskiej formy rządów, zniesienia funkcji sułtana, uwolnienia kobiet od obowiązkowych muzułmańskich zasłon i wprowadzenia alfabetu łacińskiego, wymienił zastapienie fezu kapeluszem. Na tym etapie realizacja owych zamierzeń wydawała się całkowitą fikcją, czego nie omieszkał wypomnieć protokołujący spotkanie urzędnik (Kansu, 1966, s. 131-132). Wbrew wszelkim oczekiwaniom, po upływie siedmiu lat od tego wydarzenia i niecałych dwóch od ustanowienia republiki Atatürk przystapił do realizacji swoich zapowiedzi. O ile jednak kwestią fezu i kapelusza elity polityczne i wojskowe żyły od dawna, o tyle na prowincji, zwłaszcza na wschodnich rubieżach kraju, sprawa ta albo nieznana była w ogóle, albo budziła stanowczy sprzeciw i niechęć. Pomny tego prezydent, przed przystapieniem do legislacyjnego uregulowania problemu, podjął trud osobistego zaprezentowania własnych poglądów i przekonania chłopów anatolijskich do zmiany nastawienia. Pomysł ten wpisywał się zresztą w ogólną koncepcję uprawiania polityki przez Mustafę Kemala, który po ustanowieniu republiki przemierzał obszar nowej Turcji wzdłuż i wszerz po to właśnie, by osobiście tłumaczyć jej mieszkańcom sens dokonywanych reform.

Przyjęcie wspomnianej ustawy kapeluszowej poprzedzone zostało wizytami Atatürka w czarnomorskich miejscowościach Kastamonu i İnebolu, które to spotkania w całości poświęcone zostały kwestii przewagi kapelusza nad fezem. Jak podaje ówczesna prasa, grunt był już jednak o tyle podatny, że witający wjeżdżającego do miasta prezydenta mieszkań- 
cy, widząc jego odkrytą głowę, na znak szacunku zdejmować zaczęli turbany (Îmece, 1975, s. 15). Mimo tego szokiem miał się okazać widok przywódcy, który na pierwsze spotkanie z ludnością Kastamonu przybył w białym kapeluszu. Odwołujący się do argumentów kulturowych, religijnych i ekonomicznych ${ }^{12}$ Mustafa Kemal szybko i sprawnie przekonał większość mieszkańców do swoich racji, zapewniając sobie tym samym teoretyczne przynajmniej poparcie dla zmian legislacyjnych, jakie miały nastąpić niedługo później.

Dnia 2 września 1925 roku na obszarze całej Turcji wprowadzono nakaz zobowiązujący wszystkich zatrudnionych w sferze publicznej do noszenia kapeluszy i europejskiego ubioru. Regulacja ta powtórzona została w uchwalonej 25 listopada 1925 roku ustawie o obowiązku noszenia kapeluszy, która dodatkowo rozszerzyła nakaz na wszystkich dorosłych mężczyzn (Şapka, 1925, art. 1). W ten sposób uczyniono to europejskie nakrycie głowy powszechnie obowiązującym w całej Turcji, pośrednio zakazując noszenia fezu. W ciagu kilku następnych tygodni wykupiony został cały istniejący nakład kapeluszy, co zresztą dało dobrą okazję do zarobku ich europejskim producentom. Do ponoć autentycznych anegdot z tego okresu należy przytaczana przez Dariusza Kołodziejczyka „historia pewnej anatolijskiej wioski, której mieszkańcy znaleźli w sklepie deportowanego Ormianina dziesiątki białych kapeluszy przybranych w jedwabne wstążki. Dopiero poniewczasie dowiedzieli się, że tryumfalnie obnoszona na głowach zdobycz przeznaczona była dla kobiet" (Kołodziejczyk, 2000, s. 122). W części miast położonych w Tracji i zachodniej Anatolii zorganizowano zbiorowe, symboliczne wyrzucanie fezów do morza, w środkowo anatolijskiej Konyi z kolei dzieci szkół podstawowych poprzysięgły nigdy nie założyć fezu, w Bursie dokonano publicznej egzekucji tysięcy fezów, które pocięto na drobne kawałki, w Stambule zaś dziesiątki tysięcy fezów dokonały żywota w otchłani cieśniny Bosfor (Gentizon, 1983, s. 99). Tego rodzaju anegdoty, których również w tureckiej prasie z tamtego okresu znaleźć można sporo, świadczą dobitnie o swoistym 'pospolitym ruszeniu’ wśród mieszkańców, chcących za wszelką cenę spełnić oczekiwania swego przywódcy. On sam zaś przy każdej okazji dawał

12 Argumenty ekonomiczne przeciwko noszeniu fezu dotyczyły tego, że w wyniku gospodarczego upadku Imperium Osmańskiego nakrycie głowy to sprowadzane było przeważnie z fabryk w Europie (pieniądze za zakup fezów trafiały więc za granicę), te zaś zakłady produkcyjne, które ostały się w Turcji, również znajdowały się w rękach zachodnich inwestorów. 
przykład swym wyglądem, o który dbał zwłaszcza podczas podróży do państw zachodniej Europy, chcąc przekonać ich przywódców o europejskości i postępowości swego narodu. Wbrew jednak powszechnej mobilizacji, jaka ogarnęła tureckie społeczeństwo, które uwierzyło, że dzięki kapeluszowi może stać się pełnoprawnym członkiem zachodniej hemisfery, wciąż istniały środowiska niechętne zmianom. Główny ośrodek oporu stanowiły konserwatywne miasta czarnomorskie i wschodnie, w tym między innymi Erzurum, w którym jeszcze w dzień uchwalenia ustawy wybuchły zamieszki. W ich wyniku 13 osób ostentacyjnie obnoszących fezy skazanych zostało na śmierć, która to kwestia wyjaśniona zostanie w dalszej części tekstu. Do podobnych wydarzeń doszło w tym samym czasie w Kayseri, gdzie zatrzymanych zostało ponad 300 osób, a przywódca protestu został powieszony, oraz innych miastach regionu (Aksoy, 2005, s. 115), w wyniku czego życia pozbawionych w majestacie prawa zostało 78 osób (Bahadıroğlu, 2013). Zgodnie z obowiązującym prawem karą grożącą za nienoszenie kapelusza były trzy miesiące pozbawienia wolności, powstaje więc pytanie o podstawę prawną zasądzanych wyroków śmierci. Otóż, o ile 'zwykli' uczestnicy protestów karani byli na podstawie prawa dotyczącego fezów, o tyle ich organizatorzy, przywódcy czy osoby posądzone o inspirowanie wystąpień antyrządowych podlegały ustawie o zdradzie stanu (osm. hryanet-i vataniye kanunu). Zgodnie z jej artykułem 2 karą za to przestępstwo była śmierć (Hiyanet-i, 1921, art. 2). Prawem o charakterze niejako subsydiarnym wobec niej była ustawa o trybunałach niepodległości (tur. İstiklal mahkemeleri kanunu), dająca możliwość powoływania ad hoc sądów władnych do rozstrzygania w sprawach o najcięższe przestępstwa, takie jak zdrada stanu czy organizacja powstania przeciw legalnym władzom. To zaś w praktyce oznaczało, że organem sądowniczym właściwym jurysdykcyjnie do sądzenia osób organizujących 'antykapeluszowe' protesty były nie sądy powszechne, ale właśnie trybunały niepodległości. Największym echem odbiła się sprawa muzułmańskiego hodży i autorytetu religijnego Mehmeta Atifa z İskilip (tur. İskilipli Mehmet Atif hoca). Na półtora roku przed wprowadzeniem ustawy kapeluszowej, ale już w trakcie wszechogarniającej przymusowej europeizacji i laicyzacji życia publicznego, napisał on niewielkiej objętości dzieło, które w niecałe dwa lata później stało się przyczyną skazania go na śmierć. Mimo że nie był on przeciwny czerpaniu z nauki zachodniej, a wręcz widział potrzebę postępu, sprzeciwiał się w utworze zatytułowanym Naśladowanie Zachodu a sprawa czapki (tur. „Batı taklitçiliği ve şapka”) fizycznemu upodobnianiu się muzułmanów 
do innowierców, twierdząc, że takie praktyki są zakazane wyznawcom islamu. Nie mogący wiedzieć, że wprowadzona zostanie ustawa kapeluszowa hodża sprzeciwił się swym utworem prawu, które dopiero miało być wprowadzone. Mimo że osobiście nie uczestniczył w żadnym z protestów skierowanych przeciwko ustawie, w listopadzie 1925 roku został aresztowany pod zarzutem naruszenia jej przepisów, uznano go jednak za niewinnego. Miesiąc później zatrzymano go ponownie i mimo tego, że prokuratura zażądała wyroku w wysokości 3 lat pozbawienia wolności, sąd odmówił oskarżonemu prawa do obrony i skazał go na śmierć. Hodża został powieszony 4 lutego 1926 roku.

Przytoczone przykłady ukazują wyraźnie, że naruszenie ustawy kapeluszowej traktowane było na równi z najcięższymi przestępstwami, jak zdrada stanu, szpiegostwo, dołączenie do wrogiej armii czy zabójstwo. Zasadnym wydaje się więc pytanie o to, skąd aż tak duże znaczenie przywiązywane do sprawy kapelusza. Wydawać by się mogło, że nakaz noszenia europejskiego ubioru jest tylko jednym z wielu narzędzi szeroko zakrojonej modernizacji i to pozornie mniej istotnym niż na przykład przejście $z$ alfabetu arabskiego ${ }^{13}$ na łaciński czy likwidacja bractw, zakonów i sekt religijnych. Jednak wbrew pozorom to właśnie kwestie wyglądu zewnętrznego obywateli nowej Turcji najbardziej leżały na sercu jej twórcy. Na wszelkie sugestie, że przecież liczyć się powinno to, co 'w głowie' a nie to, co 'na głowie', odpowiadał następująco: „O ile udowodnienie światu zmiany, jaka zaszła w naszych wnętrzach będzie bardzo trudne, o tyle pokazanie metamorfozy, jaką przeszła nasza zewnętrzność jest łatwe. Naprawdę, jakkolwiek nie rozwijalibyśmy się cywilizacyjnie, dopóki na naszych głowach będą fezy, dopóty Europa będzie na nas patrzeć jak dawniej. Jeśli zobaczą naszą przemianę i uwierzą w bliskość kulturową, prowadzenie $\mathrm{z}$ nami europejskiego dialogu stanie się dla nich łatwiejsze" (Erden, 2012, s. 387-388). Wypowiedź ta ukazuje, jak bardzo noszenie kapelusza było dla Atatürka nie tylko kwestią fizycznego upodobnienia się do 'prawdziwych' Europejczyków, ale przede wszystkim sprawą honoru całego narodu tureckiego. Innymi słowy, nadał on kapeluszowi taki sam walor sprawczości, jaki Bruno Latour nadaje rzeczom. Kapelusz miał być więc nie zewnętrznym przejawem zmiany, jaka dokonała się w świadomości Turków, ale narzędziem transformacji tej świadomo-

13 Język osmański zapisywany był alfabetem arabskim, nieznacznie tylko dostosowanym do lokalnych wymogów językowych. 
ści. Atatürk wierzył, że warunkiem zmiany mentalności i rzeczywistej wiary jego współobywateli we własną europejskość jest to, by najpierw uwierzyli w nią mieszkańcy Europy. Innymi słowy, zmiana stroju sygnalizować miała gotowość Turków do przyjęcia europejskich wzorców we wszystkich dziedzinach życia, aby jednak stało się to możliwe, konieczna była akceptacja ze strony zachodnich partnerów. To właśnie nakrycie głowy miało wprowadzić Turcję w poczet państw zachodnioeuropejskich i, jak wynika z przytoczonej wypowiedzi Mustafy Kemala, to ono przekonać miało ich przywódców do traktowania tego państwa jak równego sobie partnera. Rzeczywiście, jak pisano w ówczesnej prasie 'rewolucja odzieżowa' wzbudziła pozytywne reakcje europejskich polityków, którzy najwidoczniej, jak przewidział Atatürk, potrzebowali namacalnego, widocznego gołym okiem dowodu postępu cywilizacyjnego, jaki dokonywał się na gruzach upadłego Imperium Osmańskiego. Warto w tym miejscu zauważyć, że o ile podróżujące za granicę delegacje władz w Ankarze zawsze prezentowały nienaganny strój, o tyle, przynajmniej w pierwszych miesiącach po wprowadzeniu nowego prawa, zwykli obywatele nierzadko wyglądali komicznie. Wynikało to z niedoborów produkcyjnych i niedostatku kapeluszy na rynku, co - wobec obowiązujących przepisów - zmuszało mężczyzn do korzystania z jakichkolwiek nakryć głowy, przypominających kapelusz. W efekcie zdarzało się, że nosili oni damskie nakrycia głowy domowymi sposobami upodabniane do kapelusza.

Ustawa o obowiązku noszenia kapelusza, która kwestię nakrycia głowy uczyniła elementem racji stanu Republiki Turcji, zaliczana była i jest do tak zwanych głównych reform Atatürka (tur. Atatürk'ün ilke ve inkllaplart $)^{14}$. Jak stanowi artykuł 174 obowiązującej ustawy zasadniczej Republiki Turcji „Żadne prawo nie może stanowić naruszenia [...] oraz przepisów wymienionych ustaw: [...], 2. Ustawa numer 671 o obowiązku noszenia kapeluszy, [...]" (Türkiye, 1982, art. 174). To zaś oznacza, że ustawa kapeluszowa jest nie tylko wciąż obowiązującym prawem, ale jednym z niewielu aktów legislacyjnych, których moc obowiązująca potwierdzana była w każdej kolejnej konstytucji. Co więcej, zgodnie z artykułem 222 tureckiego kodeksu karnego, każdemu, kto narusza jej przepisy grozi kara pozbawienia wolności od dwóch do sześciu miesięcy (Türk, 2004, art. 222). W praktyce ustawa kapeluszowa pozostaje prawem

14 Mianem tym określane są rewolucyjne zmiany, jakich dokonano w latach 1923-1935. 
martwym i nikt nie jest karany za nienoszenie kapelusza, co nie zmienia faktu, że w świetle prawa każdy, kto go nie nosi, popełnia przestępstwo. O ile więc państwo odstappiło od karania za nienoszenie kapelusza, o tyle już poseł próbujący wejść do parlamentu w fezie na głowie $\mathrm{z}$ pewnością zostałby ukarany, dokonałby bowiem istotnego występku wobec spuścizny Atatürka. To właśnie ten aspekt powoduje, że mimo całkowitej nieadekwatności tych zapisów do czasów współczesnych, państwo tureckie nie rezygnuje z umieszczania ustawy wśród najważniejszych, wciąż będących w mocy aktów prawnych. Innymi słowy, usunięcie kuriozalnej ustawy kapeluszowej z katalogu praw obowiązujących stworzyłoby niebezpieczny precedens kwestionowania sensu głównych reform, na których opiera się istnienie republiki. Co więcej, usunięcie jej z rzeczonego katalogu wymagałoby zmiany konstytucji, co wedle tureckiego prawa jest trudne i często niemożliwe z powodów politycznych. Dnia 3 kwietnia 2013 roku poseł uważanej za prokurdyjską Partii Pokoju i Demokracji (tur. Barış ve Demokrasi Partisi) Altan Tan skierował do marszałka Tureckiego Wielkiego Zgromadzenia Narodowego wniosek o rozpatrzenie projektu ustawy znoszącej zarówno ustawę kapeluszową, jak i artykuł 222 Kodeksu karnego. Biorąc jednak pod uwagę przynależność partyjną posła i brak poparcia dla propozycji pozostałych sił parlamentarnych, pozytywne rozpatrzenie wniosku pozostaje w sferze politycznej fikcji. W efekcie, w porządku prawnym aspirującej do członkostwa w Unii Europejskiej Turcji znajduje się zapis nakazujący mężczyznom nosić kapelusz.

Jak kilkakrotnie wspomniano, odzieżowa rewolucja dokonana przez Atatürka dotyczyła wyłącznie mężczyzn, a kwestię damskich nakryć głowy pozostawiono nieuregulowana. Zgodnie z muzułmańskim prawem i obyczajem mieszkanki Imperium Osmańskiego zakrywały włosy (a często i całe ciało) chustą bądź hijabem, co w całkowicie zislamizowanym społeczeństwie uchodziło za absolutną normę obyczajową, służącą ochronie kobiet przed pożądliwymi spojrzeniami mężczyzn. Kemalistowscy reformatorzy, wiedząc, jak silnie chusta zakorzeniona jest w muzułmańskiej tradycji, zdecydowali się nie wprowadzać żadnych w tej materii regulacji, pozostawiając kwestię zakazu (bądź nie) noszenia chust władzom lokalnym. Innymi słowy, mimo że sam Mustafa Kemal był zdeklarowanym przeciwnikiem zasłaniania włosów przez kobiety i marzył o całkowitym wyrugowaniu chust przynajmniej ze sfery publicznej, nie odważył się na całkowite ich zakazanie. W tym miejscu warto wspomnieć o jedynym przypadku kobiety, która stracona została za naruszenie ustawy kapeluszowej. Miało to miejsce w listopadzie 1925 roku, a więc od razu po 
wprowadzeniu ustawy, w Erzurum, gdzie jedna z uczestniczek protestu obrzuciła wyzwiskami i oskarżeniami o zdradę wiary żołnierzy noszących kapelusze. Podczas wykonywania wyroku jej twarz owinięta była szalem tak, by nikt z obserwatorów nie mógł rozpoznać jej płci. Stąd jedyna kobieta-ofiara ustawy kapeluszowej do dziś nazywana jest Turcji Siostrą w szalu (tur. şalcı bacı). Jak wskazano, władze młodej republiki nie zdecydowały się na wprowadzenie formalnego zakazu zakrywania włosów przez kobiety, w praktyce jednak noszenie chust stało się niemożliwe wraz z wprowadzeniem najważniejszych reform, w tym ustawy kapeluszowej. Mimo braku prawnych ku temu przeszkód, muzułmanki nie odkrywające włosów nie mogły podejmować pracy w jakichkolwiek instytucjach publicznych. To zaś oznaczało de facto zepchnięcie ich do sfery prywatnej i pozbawienie miejsca w społeczeństwie. Islamska chusta uosabiała w oczach Atatürka, podobnie jak fez, wszystko to, co w jego opinii zadecydowało o upadku Imperium Osmańskiego, w tym przede wszystkim, będącą źródłem zła i zapóźnienia religię. Realizacja marzenia o zeuropeizowaniu Turków i uczynieniu Turcji państwem prawdziwie europejskim wymagała w jego opinii daleko idących poświęceń, a pierwszą 'ofiarą' miały być właśnie wiara i obrządek muzułmański. W największym skrócie, przyczyny tak głębokiej niechęci Mustafy Kemala do religii wynikały po pierwsze z przekonania o niemożności pogodzenia jej z nauką, w której widział przyszłość Turcji, po drugie zaś z przeświadczenia, że tym, co powinno spajać naród jest nie wiara czy wspólny obrządek, a poczucie 'bycia narodem'. Aby ten cel osiagnąć, zapowiedziano odrzucenie wszelkich dotychczasowych spoiw, które zastąpione miały być przez zupełnie nową koncepcję świeckiego i nowoczesnego narodu tureckiego. Mająca zapewnić przyjęcie Turcji w poczet państw europejskich laicyzacja dokonywana była więc odgórnie, a odrzucenie (usankcjonowane prawnie) fezu i chusty (nieusankcjonowane prawnie) stanowić miało wysłany pod adresem tychże sygnał gotowości i chęci zmiany. O skutkach owej narzuconej społeczeństwu laicyzacji wspomniane zostanie w dalszej części tekstu, wcześniej warto jednak odnieść się do tego, czym w rozumieniu Atatürka była kultura europejska, którą tak umiłował. Pojawiać się może bowiem dysonans związany z tym, że skoro odrzucał on islam - religię, w której teoretycznie został wychowany - jak mógł ze zrozumieniem odnosić się do dominującego przecież w Europie chrześcijaństwa. Na tego rodzaju zarzuty czy wątpliwości reagował jednak zawsze podobnie, twierdząc, że ,kultura europejska to ani chrześcijaństwo, ani renesans, ani reformacja, ani starożytność, ani nawet kapitalizm, ale wszystko to po 
trochu" (Baykal, 1988, s. 748). Jednoznacznie dostrzegał więc znaczenie religii w kształtowaniu się tego, co rozumiał pod pojęciem kultury europejskiej, podkreślał jednak rolę innych czynników, które w formowaniu kultur ludów muzułmańskich właściwie nie wstępowały. Innymi słowy, podczas gdy na kontynencie europejskim religia od końca średniowiecza pozostawała jednym tylko z czynników tworzących cywilizację, w imperium dominowała ona nad wszelkimi innymi, nie pozostawiając miejsca na rozwój świeckiej sztuki czy nauki. Przekonany o słuszności swego poglądu Atatürk podjął się przeprowadzenia głębokiej, wielopłaszczyznowej laicyzacji, której symbolicznym początkiem i zewnętrznym przejawem miało być odrzucenie religijnych nakryć głowy, o czym wspomniano kilkakrotnie. O ile jednak historia fezu w młodej republice okazała się zaskakująco krótka, o tyle losy muzułmańskiej chusty potoczyły się inaczej, a rola, jaką pełniła ona i wciąż pełni w procesie europeizacji Turcji wielokrotnie ewoluowała.

Wprowadzenie formalnego zakazu noszenia fezu i bezwzględna egzekucja tego przepisu szybko zaowocowały jego rzeczywistym wyeliminowaniem ze sfery publicznej. Zasygnalizowany wcześniej problem buntów i protestów, do jakich dochodziło w pierwszych miesiącach po wprowadzeniu ustawy kapeluszowej okazał się przejściowym, nowym władzom udało się bowiem skutecznie wzbudzić strach przed jej naruszaniem. W efekcie, kapelusz bardzo szybko stał się powszechnie stosowanym nakryciem głowy, a fez na wiele lat zniknął ze sfery publicznej. Dziś spotyka się go właściwie wyłącznie na bazarach, gdzie sprzedawany jest turystom jako tradycyjna turecka pamiątka. Brak prawnego zakazu noszenia chusty i fakt, iż jej użytkowniczkami były kobiety, a więc grupa mniej zaangażowana w życie publiczne, spowodowały, że historia tego islamskiego nakrycia włosów potoczyła się zgoła inaczej.

\section{Muzułmańska chusta - bliżej czy dalej Europy?}

W ciagu pierwszych kilku dekad istnienia republiki eliminowanie zakrytych kobiet ze sfery publicznej stało się swego rodzaju ususem, który choć pozbawiony podstawy prawnej, szybko zaczął dotyczyć całego terytorium państwa. Zobligowani do respektowania linii ideologicznej wyznaczonej przez Atatürka urzędnicy wszystkich szczebli konsekwentnie odmawiali przyjmowania do pracy takich kobiet, przy czym dotyczyło to nie tylko jednostek administracji państwowej, ale wszystkich instytucji 
publicznych, w tym szpitali, placówek pocztowych, a przede wszystkim szkół i uczelni wyższych. Pytani o podstawę odmowy zatrudnienia decydenci konsekwentnie powoływali się na konstytucyjny zapis dotyczący laickości państwa ${ }^{15}$, którego naruszeniem byłoby przyjęcie do pracy kobiety o zakrytych włosach. W efekcie, zdecydowana ich większość skazana została na pozostanie w sferze prywatnej, choć oczywiście prowadzone były kampanie społeczne, mające zachęcić Turczynki do odrzucenia reliktu wstydliwej przeszłości, jakim były chusty. Największą tego orędowniczką i niejako wykonawcą nowej ideologii była żona Mustafy Kemala Latife Uşakk1, podczas wszelkich zagranicznych wizyt występująca w nienagannym stroju skrojonym wprost na europejską modę, w takiej samej fryzurze i makijażu. Efektem presji wywieranej w tej materii na kobiety była albo stanowiąca naruszenie zasad religii decyzja o rezygnacji z chusty, albo postanowienie o porzuceniu zamiaru podjęcia pracy bądź nauki. Jednocześnie, istotną grupę stanowiły kobiety, które gotowe były odkryć włosy, nie godziły się jednak na to ich konserwatywne rodziny. W rezultacie szansę na edukację bądź zatrudnienie utraciła ta część z nich, która w razie możliwości pozostania zakrytą któreś z tych zajęć by podjęła. Pierwsze starania o rozpoczęcie debaty nad możliwością przywrócenia chust do sfery publicznej nastąpiły w drugiej połowie lat sześćdziesiątych XX wieku, a impulsem do ich podjęcia stały się wydarzenia z 1966 roku. Wówczas bowiem miała miejsce pierwsza próba wejścia na wykład uniwersytecki z zakrytymi włosami podjęta nota bene na wydziale teologicznym uniwersytetu w Ankarze. Presja wywarta na studentkę i stanowczość wykładowcy skłoniły ją do porzucenia podjętego zamiaru i kontynuowania nauki z odkrytymi włosami. Rok później inna studentka tego samego wydziału nie ugięła się i uczęszczała na wykłady w chuście, co w niedługim okresie spowodowało wzrost liczby jej podobnych do sześciu. $\mathrm{W}$ efekcie ona sama, jako przywódczyni ruchu, została relegowana, co z kolei skłoniło jej towarzyszki do zdjęcia chust. Podobne wydarzenia, jak również zdejmowanie studentkom nakryć włosów siła, miały miejsce przez całe lata siedemdziesiąte i osiemdziesiąte XX wieku. Jednocześnie, liczba studentek próbujących uczestniczyć w zajęciach regularnie rosła, a kilku z nich udało się nawet ukończyć studia (Aksoy, 2005, s. 139-143). Aby jednoznacznie ukrócić te praktyki i położyć kres opisywanemu zja-

15 Zapis ten pojawił się już w konstytucji z 1924 roku i odtąd powtarzany jest w każdej kolejnej ustawie zasadniczej. 
wisku turecka Rada do spraw Szkolnictwa Wyższego (tur. Yüksesögrrenim Kurulu, YÖK) wydała zarządzenie zakazujące noszenia chust we wszystkich szkołach wyższych. Mimo kilku prób zaskarżenia przepisu, turecki Sąd Konstytucyjny ${ }^{16}$ odmawiał orzeczenia jego niezgodności z konstytucją. Dodatkowo, w 1997 roku przewodniczący rady wydał odrębne zarządzenie zakazujące wpuszczania kobiet zakrywających włosy nie tylko do budynku uczelni, ale i na cały obszar danej jednostki, w tym kampusy uniwersyteckie. Rok później ofiarą tych regulacji stała się żona byłego już prezydenta Turcji, Hayrünnisa Gül, która mimo zdobycia odpowiedniej liczby punktów nie została zarejestrowana jako studentka, co skłoniło ją do skierowania sprawy do Europejskiego Trybunału Praw Człowieka. Sprawę wycofała dobrowolnie w 2007 roku, po wyborze jej męża na urząd prezydenta. Rok później rządząca, otwarcie odwołująca się do swych islamskich korzeni Partia Sprawiedliwości i Rozwoju (tur. Adalet ve Kalkınma Partisi, $A K P$ ) podjęła najpoważniejsząjak dotąd próbę zmiany konstytucji tak, by zapis o świeckim charakterze państwa nie mógł dłużej być podstawą odmowy edukacji wyższej dziewczętom zakrywającym włosy. W pierwszych miesiącach 2008 roku partia rządząca w porozumieniu ze skrajnie prawicową i nacjonalistyczną Partią Ruchu Nacjonalistycznego (tur. Milliyetçi Hareket Partisi, MHP) przedłożyła i wspólnymi siłami przegłosowała pakiet poprawek do konstytucji. Dotyczący edukacji i szkolnictwa wyższego artykuł 42 ustawy zasadniczej z 1982 roku miał zostać w swym nowym brzmieniu uzupełniony o zapis, stanowiący, że „Prawo do dostępu do szkolnictwa wyższego nie może być ograniczone z jakichkolwiek przyczyn niesformułowanych wyraźnie w ustawach. Ograniczenia te określa odpowiednia ustawa" (Anayasa Mahkemesi, 2008). Treść tego przepisu, mimo że nie odnosząca się bezpośrednio do noszenia muzułmańskich nakryć głowy na uczelniach wyższych, wyraźnie miała na celu uczynienie tej kwestii możliwą. Świadczy o tym zapis o „przyczynach niesformułowanych wyraźnie w ustawach”, w którym ustawodawca poczynił aluzję do braku formalnego zakazu zakrywania włosów, mimo którego dziewczęta w chustach nie są przyjmowane na uniwersytety. To właśnie możliwość takiej interpretacji przyjętych zmian zaniepokoiła dwie partie opozycyjne, w tym kemalistowską Republikańską Partię Ludową (tur. Cumhuriyet Halk Partisi, CHP), które zde-

16 Tur. Anayasa mahkemesi - organ badający zgodność aktów niższego rzędu z konstytucją, odpowiednik polskiego Trybunału Konstytucyjnego. 
cydowały się na ich zaskarżenie do Sądu Konstytucyjnego. Ten zaś wykazał się daleko, jak na Turcję, idącą niezależnością od władz w Ankarze i orzekł niezgodność przepisów z konstytucją. W efekcie turecka ustawa zasadnicza pozostała $\mathrm{w}$ tej materii niezmieniona i do dziś ${ }^{17}$ nie było w tej materii żadnych zmian legislacyjnych. Nie oznacza to jednak, by sprawa chust $\mathrm{w}$ miejscach publicznych, w tym przede wszystkim na uniwersytetach, przycichła bądź zniknęła z dyskursu publicznego. Mimo braku legislacyjnych gwarancji dla możliwości noszenia chust na uniwersytetach, w praktyce od roku 2012 jest to tolerowane, przy czym kwestia ta pozostaje jedną z częściej dyskutowanych, ale i newralgicznych i konfliktogennych we współczesnej Turcji. Co więcej, podejście do niej urosło do rangi miernika europejskości i nowoczesności poszczególnych stron debaty publicznej. Innymi słowy, w niecałe sto lat po śmierci Atatürka, w dyskusji nad pożądanym kierunkiem rozwoju, fez zastąpiony został przez muzułmańską chustę.

Jak zaznaczono, nieformalny zakaz zakrywania włosów przez muzułmanki pracujące w sferze publicznej i studentki był niejako naturalną konsekwencją rewolucji przeprowadzonej przez Mustafę Kemala. Fez i chusta stanowiły dla niego symbol pogrążenia się Turcji w znienawidzonym Oriencie i przeszkodą w jej europeizacji i modernizacji. O ile jednak noszenie fezu zostało zakazane mocą ustawy kapeluszowej, o tyle nawet sam prezydent, pomny szczególnej pozycji kobiety w islamie, nie zdecydował się na wprowadzenie analogicznego zapisu dotyczącego chust. Jednak de facto zostały one wyeliminowane ze sfery publicznej.

Taki stan rzeczy, będący emanacją świeckości państwa, nie był kwestionowany w istotny sposób właściwie do roku 2002, czyli od momentu dojścia do władzy rządzącej AKP premiera Recepa Tayyipa Erdoğana. Objęcie rządów przez konserwatywną i otwarcie przywiązaną do wartości islamu Partię Sprawiedliwości i Rozwoju szybko doprowadziło do rozpoczęcia dyskusji nad zasadnością respektowania zakazu narzuconego przez Atatürka i jego następców. W dyskursie tym, przybierającym na intensywności z każdym mijającym rokiem, wskazać można dwie opozycyjne wobec siebie strony: kemalistów z CHP (określających siebie również mianem republikanów) i ich organizacje satelickie oraz umiarkowanych islamistów z AKP (określających siebie często demokratami) i bliskie im

17 Stan na koniec 2014 roku. 
środowiska religijne, skupione wokół meczetów ${ }^{18}$. Paradoksalnie, punktem, w którym siły te się spotykają jest argument o konieczności dalszej europeizacji Turcji, przez każdą z nich używany i interpretowany na poparcie własnej tezy. I tak, kręgi odwołujące się do dziedzictwa Atatürka, kontynuujące jego myśl i wizję państwa świeckiego i nowoczesnego, sprzeciwiają się zdecydowanie możliwości dopuszczenia zakrywania włosów przez studentki i kobiety pracujące w instytucjach publicznych. Taką postawę uzasadniają twierdzeniem o niedopuszczalności podważania woli twórcy współczesnej Turcji, który pragnął widzieć swe państwo równym wobec europejskich partnerów, co z kolei wyklucza takie 'zabobony', jak chusta chroniąca przed rzekomo pożądliwymi spojrzeniami mężczyzn. W nowoczesnym, laickim państwie kobieta jest bowiem takim samym obywatelem, jak mężczyzna, a nie słabą, kruchą istotą, narażoną na naganne popędy tego ostatniego. Co więcej, dopuszczenie zakrywających się kobiet do pracy w instytucjach publicznych bądź nauki byłoby przejawem cofania się Turcji do czasów osmańskich, a więc zniweczeniem dzieła ostatnich dziewięćdziesięciu lat. To zaś stanowiło by sygnał odwrotu od obranego przez Atatürka kierunku proeuropejskiego rozwoju na rzecz zwrotu w stronę islamu. Stąd już tylko krok do podważenia zasady świeckości państwa, co z kolei prowadzić może do zanegowania innych reform Atatürka. Innymi słowy, kontynuatorom kemalizmu stopniowe przywracanie chust do sfery publicznej jawi się jako krok wstecz, pogrążający Turcję w otchłani politycznego islamu i oddalający ją od marzenia o staniu się pełnoprawnym członkiem europejskiej społeczności. Dodatkowo, rzuca w ich opinii negatywne światło na turecką kandydaturę do Unii Europejskiej i spowolnia trwający od 3 października 2005 roku proces akcesyjny, i tak już obarczony szeregiem problemów.

Przytoczone argumenty pozostających w opozycji parlamentarnej kemalistów z CHP odrzucane są przez partię rządząca, również opierającą swe stanowisko na twierdzeniach nawiązujących do europejskości i nowoczesności Turcji. Opiera się ono na przekonaniu, że zgoda na przywrócenie chust do sfery publicznej nie stoi w sprzeczności z zasadą świeckości państwa, ta bowiem polega na niezależności jego władz od du-

18 Prócz nich znaczenie na tureckiej stronie politycznej mają jeszcze dwie siły: nacjonalistyczna MHP, dla której kwestia chust ma raczej walor kulturowy, nieodłącznie kojarzy się bowiem z umiłowaną przez jej członków tureckością oraz BDP, uważana za prokurdyjską partia, dla której ważniejsze od chust jest poszerzenie praw mniejszości kurdyjskiej. 
chowieństwa i nie ma nic wspólnego z ubiorem jego urzędników czy tym bardziej studentów. Celem nie jest więc negowanie spuścizny Mustafy Kemala, jego zasług dla tureckiej państwowości nikt bowiem nie kwestionuje, ale dostosowanie działań państwa do wymogów XXI wieku. O ile więc stulecie wcześniej, kiedy pod znakiem zapytania stało to, czy jakakolwiek forma tureckiej państwowości będzie miała szansę na przetrwanie, radykalne reformy mogły wydawać się koniecznymi, o tyle współcześnie nie ma żadnego powodu, by tę linię ideologiczną kontynuować. Co więcej, jak twierdzi były już, wieloletni premier Erdoğan, zgodnie z podstawową zasadą demokratycznego państwa prawa, to, co nie jest zakazane, jest dozwolone (Erdoğan'dan). Skoro więc w tureckim porządku prawnym nie istnieje formalny zakaz zakrywania włosów w instytucjach publicznych, nic nie stoi na przeszkodzie, by czyniące to kobiety podejmowały w nich pracę czy naukę. Tym jednak, na co zwolennicy tego podejścia kładą największy nacisk, jest kwestia praw człowieka. Otóż, przywołując wypracowaną w ramach ONZ, uniwersalną koncepcję praw człowieka, oraz regionalne, wykształcone na kontynencie europejskim systemy ochrony praw jednostki, twierdzą oni, że kwestia chust to przede wszystkim kwestia wolności wyznania. Innymi słowy, państwo tureckie, nie zezwalając dotychczas na zakrywanie włosów przez kobiety, naruszało własne zobowiązania międzynarodowe. W tym momencie zaznaczyć należy, że kolejne rządy, właśnie w ramach europeizacji zainicjowanej przez Atatürka, przystępowały do wszystkich najważniejszych dokumentów z zakresu ochrony praw człowieka. I tak, Turcja, jako członek ONZ, przystąpiła do Powszechnej Deklaracji Praw Człowieka, Deklaracji Praw Osób Należących do Mniejszości Narodowych lub Etnicznych, Religijnych i Językowych, jest stroną Międzynarodowego Paktu Praw Obywatelskich i Politycznych, Konwencji o Ochronie Praw Człowieka i Podstawowych Wolności, a także państwem kandydującym do Unii Europejskiej, co zobowiązuje ją do przestrzegania w momencie akcesji całości unijnego dorobku prawnego, w tym Karty Praw Podstawowych. Każdy z tych dokumentów zawiera zapisy gwarantujące wolność wyznania i to na nie właśnie powołują się zwolennicy przywrócenia chust do sfery publicznej. Skoro bowiem Turcja była na tyle 'europejska' by przyjąć prawnomiędzynarodowe zobowiązania wypracowywane w ramach ONZ, Rady Europy, KBWE/OBWE oraz rozpocząć starania o członkostwo w UE, powinna konsekwentnie się z nich wywiązywać, w tym zapewnić swym obywatelom pełnię wolności wyznania i praktyk religijnych. Inaczej rzecz ujmując, to właśnie stosunek do sprawy chust jest 'papierkiem lakmusowym' rzeczywistego stopnia europeizacji Turcji. Zgodnie z tym 
poglądem, obawa przed ich powrotem do sfery publicznej, świadczy o niedojrzałości tureckiej demokracji. Ich stopniowy powrót do sfery publicznej nie tylko, że nie jest krokiem wstecz czy symbolem kulturowego zacofania, ale wręcz dowodzi ukształtowania się w Turcji rzeczywistego pluralizmu i wolności światopoglądowej, tak charakterystycznych dla państw zachodniej Europy ${ }^{19}$.

W ten sposób dwa opozycyjne obozy polityczne, reprezentujące odmienne zgoła grupy społeczne, uczyniły z muzułmańskiej chusty jeden z najważniejszych tematów dyskursu publicznego, nadając jej jednocześnie walor symbolu kierunku, w jakim współczesna Turcja powinna się rozwijać. Spór ów zyskał również wymiar międzynarodowy, kiedy studentka, której odmówiono wstępu na egzamin pisemny z powodu zakrycia włosów, zdecydowała się skierować sprawę do Europejskiego Trybunału Praw Człowieka, stojącego na straży przestrzegania zapisów Europejskiej Konwencji o Ochronie Praw Człowieka i Podstawowych Wolności. Skarżąca powołała się na artykuł 9 aktu gwarantujący wolność myśli, sumienia i wyznania (Konwencja, 1950, art. 9). Trybunał po rozpatrzeniu sprawy nie stwierdził naruszenia tego przepisu, twierdząc, że podjęte przez władze uczelni ograniczenia wolności wyznania były proporcjonalne do celu, który chciały osiagnąć, a którym była ochrona zasady świeckości jednostki edukacyjnej. Stanowisko to sędziowie podparli tezą, zgodnie z którą laickość, stanowiąca fundament republiki, zyskała rangę konstytucyjną i stanowi gwarancję wartości demokratycznych, w tym wolności religijnej, ale również chroni jednostkę przed arbitralną ingerencją państwa z jednej strony i presją ruchów ekstremistycznych z drugiej. Zasada wolności wyznania może być w proporcjonalny sposób ograniczana celem ochrony tych wartości (Leyla Şahin vs. Turkey, 2004), Trybunał wydając więc powyższe orzeczenie dał wyraz przekonaniu o tym, że kwestia chusty dawno przestała być w Turcji jedynie sprawą wolności wyznania i w dużej mierze uległa upolitycznieniu. W tej sytuacji właściwszym będzie pozostawienie problemu $\mathrm{w}$ gestii władz państwowych, bez angażowania środków prawa międzynarodowego. W tym kontekście brak prawnego usankcjonowania zakazu noszenia chust czyni tę kwestię wy-

19 W tym kontekście zaznaczyć należy, że jest to w dużej mierze polityczna retoryka rządzącej AKP, nastawiona na przekonanie zagranicznych partnerów o rzeczywistej chęci wstapienia do UE i kontynuowania procesu akcesyjnego. Powszechnie wiadomym jest jednak, że poparcie dla tej koncepcji, tak wśród społeczeństwa, jak i elit rządzących spada, co jednak nie jest przedmiotem niniejszej analizy. 
jątkowo zależną od aktualnego klimatu politycznego. Mimo niepowodzenia próby zmiany konstytucji w 2008 roku, o czym wspomniano powyżej, sprawująca rządy AKP nie ustaje w dążeniach do realizacji swojego celu, jakim jest przywrócenie chust w sferze publicznej, w tym przede wszystkim na uniwersytetach. Nie mogąc więc doprowadzić do zmiany ustawy zasadniczej, rząd premiera Erdoğana, za pośrednictwem ministerstwa edukacji narodowej, pozostawił sprawę w gestii rektorów poszczególnych uczelni, dając im tym samym do zrozumienia, że kontynuowanie zakazu nie spotka się z jego aprobatą. W efekcie, w ciaggu ostatnich kilku lat lawinowo rośnie liczba uczelni otwierających swe progi dla studentek w chustach, wiadomym jest jednak, że ewentualna zmiana powyborcza przyniesie kolejne zaostrzenie polityki wobec takich dziewcząt. Jednocześnie, ciesząca się rzeczywistym, blisko pięćdziesięcioprocentowym poparciem AKP ufa w kolejne zwycięstwo w wyborach w 2015 roku na tyle, że w kwietniu 2013 roku parlamentarna komisja regulaminowa rozpoczęła prace nad zmianą regulaminu tak, by możliwy stał się wybór na stanowiska poselskie kobiet, które zakrywają włosy chustami. Dotychczas ściśle przestrzegana była zasada niewyrażania zgody na obecność w parlamencie kobiet w chustach, czego ofiarami stały się dwie byłe pierwsze damy Turcji - żona byłego premiera Erdoğana i prezydenta Güla, niedopuszczone do udziału w uroczystym zaprzysiężeniu swoich mężów. Obie jednak uczestniczyły w ich służbowych wyjazdach zagranicznych, z dumą nosząc chusty tak, jak niegdyś Atatürk i jego towarzysze obnosili kapelusze.

Jak starano się wykazać, muzułmańska chusta, służąca w swym pierwotnym, religijnym znaczeniu ochronie kobiet przed spojrzeniami mężczyzn, zyskała we współczesnej Turcji znaczenie politycznego symbolu. Według przeciwników jej przywrócenia do sfery publicznej uosabia ona polityczny islam, odwrót Turcji od wartości, na których zbudowano republikę i powrót do kulturowego zacofania, mającego swe korzenie w religii. Według kręgów sprzymierzonych wokół byłego premiera, a obecnego prezydent Erdoğana ${ }^{20}$ jest dokładnie odwrotnie - gotowość do zaakceptowania widoku chusty w urzędach czy uniwersytetach jest przejawem dojrzałości tureckiej demokracji i rzeczywistego pluralizmu wypracowanego w trakcie istnienia republiki. Jednocześnie, obie strony zręcznie wykorzystują argument 'europejskości’ i 'europeizacji’ Turcji. Dla pierwszych

20 R. T. Erdoğan w sierpniu 2014 roku wybrany został pierwszym w historii republiki prezydentem pochodzącym z wyborów powszechnych. 
chusta to narzędzie spowolnienia procesu modernizacji i wprowadzania Turcji w poczet państw uznawanych za europejskie. Dla drugich symbol zwieńczenia tego procesu sukcesem, 'żywy dowód' tureckiej demokracji i wolności światopoglądowej. W ten sposób chusta zaczęła żyć niejako własnym życiem, wychodząc ze swej pierwotnej funkcji i stając się pełnoprawnym uczestnikiem procesów politycznych zachodzących we współczesnej Turcji. Samoistnie nasuwa się tu analogia do ról, jakie niecałe stulecie wcześniej nadano fezowi i kapeluszowi - podczas, gdy ten pierwszy uznano za źródło mentalnego zapóźnienia, drugiemu przypisano wręcz magiczną moc europeizacji i unowocześnienia zacofanego społeczeństwa. Podobne role przypisywane są dziś chuście. Podczas gdy jej przeciwnicy widzą w niej uosobienie reislamizacji społeczeństwa tureckiego, zwolennicy za warunek sina qua non rzeczywistej modernizacji uważająjej przywrócenie do sfery publicznej. Wszyscy natomiast przypisują tym trzem nakryciom głowy pewną sprawczość, nie ograniczając się do upatrywania w nich tylko symboli tego czy innego procesu, ale nadają im niejako moc samodzielnego funkcjonowania. Taki sposób patrzenia na przybliżone w tej analizie zjawiska, oparty na teoretycznym koncepcie Bruno Latoura, pokazuje, iż możliwe jest spojrzenie na procesy z zakresu stosunków międzynarodowych przez pryzmat rzeczy, a nie ludzi bądź zjawisk społecznych tak, jakby przedmioty w ogóle nie istniały. Jak zaznaczono na samym początku, nie jest intencją Latoura udowodnienie, że to one inicjują procesy lub, że to od nich w największej mierze ich przebieg zależy. Fałszywym byłoby więc zarówno stwierdzenie, że bez kapelusza nie było by modernizacji Turcji, jak i to, że pozostawienie fezu jako dopuszczalnego nakrycia głowy uniemożliwiło by ten proces. Podobnie trudno jednoznacznie odpowiedzieć na pytanie o to, którą z przypisywanych jej funkcji muzułmańska chusta pełni - oddala, a może przybliża Turcję do państw zachodniej Europy? Celem niniejszej analizy nie była jednak odpowiedź na te pytania, ale wykazanie, że każde ze wspomnianych w niej nakryć głowy stało się w niezauważalny sposób aktorem procesu modernizacji i europeizacji Turcji, ponieważ, jak twierdzi Latour, aktorem jest „każda rzecz, która zmienia stan rzeczy, która wprowadza jakąśs różnicę" (Latour, 2010, s. 537).

\section{Bibliografia}

Aksoy M. (2005), Başörtüsü, türban, batılllaşma, laikleşmesi laiklik ve örtünme, Kitap Yayınevi, İstanbul. 
Anayasa Mahkemesi 5/6/2008 tarih ve E. 2008/16, K. 2008/116 sayll karart, http://www.anayasa.gen.tr/1982ay.htm, 23.07.2013.

Atay F. R. (2004), Çankaya, Pozitif Yayıncılık, İstanbul.

Aydemir S. Ş. (1981), Tek Adam, III, Remzi Kitapevi, İstanbul.

Bahadıroğlu Y., Şapka inkılabında kaç kişi asıldt?, http://www.timeturk.com/tr/makale/yavuz-bahadiroglu/sapka-inkilabinda-kac-kisi-asildi.html, 18.072013.

Baykal H. (1988), Atatürkçü çağdaşlaşma yönünden Türkiye'nin Avrupa topluklarına tam üyeliği, ,, Atatürk Araştırma Merkezi Dergisi”, Cilt IV, say1 12.

Erden S. (2012), Modern Türkiye'de Siyasi Düşünce Ansiklopedisi III: Modernleşme ve Batılılaşma, İletişim Yayınları, Ankara.

Erdoğan'dan kamuda başörtüsü açıklaması, http://www.internethaber.com/erdogandan-kamuda-basortusu-aciklamasi-508528h.htm, 23.07.2013.

Gentizon P. (1983), Mustafa Kemal ve uyanan doğu, Bilgi Yayınevi, Ankara.

Îmece M. (1975), Atatürk'ün şapka devrimde Kastamonu ve İnebolu seyahatleri, Türk tarih Kurumu Basinevi, Ankara.

Kansu M. M. (1966), Erzurum'dan ölümüne kadar Atatürk ile beraber I, Türk Tarih Kurumu Basınevi, Ankara.

Kołodziejczyk D. (2000), Turcja, Wydawnictwo TRIO, Warszawa.

Konwencja o Ochronie Praw Człowieka i Podstawowych Wolności, Rzym 1950, Dz. U. 1993, Nr 61, poz. 284.

Latour B. (2010), Przedmioty także posiadaja sprawczość, w: Teoria wiedzy o przeszłości na tle wspótczesnej humanistyki, red. E. Domańska, Wydawnictwo Poznańskie, Poznań.

Leyla Şahin v. Turkey (2004), No: 44774/98, http://sim.law.uu.nl/SIM/CaseLaw/hof.nsf/ 1d4d0dd240bfee7ec12568490035df05/c41c422237274eebc1256ec200325d6b? OpenDocument, 23.07.2013.

Şapka iktisası hakkında kanun No: 671, „Resmî Gazete” 28.11.1925.

Sitembölükbaş1, Ş. (1996), Kültür Devrimleri Yönüyle Atatürk Reformlarl, Türkiye Günlüğü Yaz, sayı: 56.

Türk ceza kanunu No: 5237, „Resmî Gazete” 12.10.2004.

1982 Türkiye Cumhuriyeti anayasası No: 2709, „Resmî Gazete” 9.11.1982.

Hat versus fez - on the role of headgear in the Europeanisation of Turkey

\section{Summary}

The aim of this publication is to depart from traditional perspectives and research methods in international relations and to take an attempt to analyze the process of modernization of Turkey through the prism of Objects - fez, hat and hijab. The starting 
point for the deliberations is Bruno Latour's Object-oriented ontology which's essence is statement that dichotomy between these what belong to social world and those what is material is completely unfounded. The Objects are indeed the ground and support for fragile relations and processes and create a so-called nonhuman factor, which is subject of interest of posthuman perspective. The author, using Latour's theory as a theoretical basis, analyzes the role of headgears which evolved from common daily use things into vehcile of state- and nation-building processes. 